\title{
Przecindzialanie zaKażeniom i ChOROBOM zaKaźnyM W PODMIOTACH LECZNICZYCH W KONTEKŚCIE ZWOLNIENIA Z OBOWIĄZKU ZACHOWANIA TAJEMNICY LEKARSKIEJ
}

\section{Wstęp}

Przeciwdziałanie zakażeniom i chorobom zakaźnym w podmiotach leczniczych jest jednym z podstawowych obowiązków pracowników ochrony zdrowia ${ }^{1}$. Tylko $\mathrm{w}$ enumeratywnie wyliczonych przypadkach lekarz może ujawnić informacje o chorobie czy zakażeniu. Celem artykułu jest przedstawienie unormowań prawnych oraz stanowiska doktryny i orzecznictwa dotyczących zwolnienia lekarza z obowiązku zachowania tajemnicy lekarskiej w zakresie zapobiegania oraz zwalczania zakażeń i chorób zakaźnych.

\section{Zakres przedmiotowy tajemnicy lekarskiej}

Zgodnie z ustawą z dnia 5.12.1996 r. o zawodach lekarza i lekarza dentysty lekarz jest zobowiązany do zachowania tajemnicy lekarskiej². Jak słusznie zauważa P. Kardas, „z punktu widzenia informacji przekazywanej przedstawicielom zawodów zaufania publicznego zagwarantowanie

* Dr nauk prawn., Uniwersytet Medyczny w Lublinie, Katedra Zdrowia Publicznego e-mail: jolapacian@gmail.com.

${ }^{1}$ R. Kubiak, Prawo medyczne, Warszawa 2014, s. 209 i n.

${ }^{2}$ Ustawa z dnia 5.12.1996 r. o zawodach lekarza i lekarza dentysty, tekst jedn., Dz.U. z 2017 r. poz. 125 z późn. zm. 
realnej ochrony prywatności wymaga wprowadzenia do systemu prawa rozwiązań gwarantujących zachowanie tych informacji w poufności oraz wykorzystania ich wyłącznie w celu realizacji powinności zawodowych"3. Zasadne jest bowiem, że to właśnie obowiązek zachowania tajemnicy lekarskiej wynika z konstytucyjnego obowiązku ukształtowania systemu prawa. Dodatkowo należy podkreślić, że ma swoje umocowanie w art. 2 Konstytucji RP, zgodnie z którym Rzeczpospolita Polska jest demokratycznym państwem prawnym, urzeczywistniającym zasady sprawiedliwości społecznej .

Dodatkowo D. Rydlichowska podnosi, że w doniesieniu do obowiązku zachowania tajemnicy lekarskiej charakterystyczne jest łączne istnienie następujących przesłanek. Po pierwsze, osoba mająca dostęp do informacji o stanie zdrowia pacjenta musi wykonywać zawód lekarza. Po drugie, dostęp do tajemnicy lekarskiej musi być nieodzownie związany z wykonywaniem zawodu lekarza. Po trzecie, zarówno informacje o pacjencie pochodzące od niego, jak i od osób trzecich, dotyczące nie tylko jego stanu zdrowia, objęte są ochroną na gruncie prawa ${ }^{5}$. Zasadne jest zatem, że tylko kumulatywne występowanie tych przesłanek przesądza o powstaniu po stronie lekarza obowiązku w zakresie zachowania tajemnicy lekarskiej.

Norma prawna nakładająca ten obowiązek ma charakter ius cogens, co oznacza, że wyłącznie w ściśle uzasadnionych przypadkach lekarz może być $\mathrm{z}$ tego obowiązku zwolniony. Tylko w wyjątkach przewidzianych w przepisach szczególnych lekarz jest zwolniony z obowiązku zachowania tajemnicy lekarskiej. Te wyjątki zostały wyodrębnione w art. 40 ust. 2 tejże ustawy.

Artykuł 40 ust. 1 stanowi, że lekarz ma obowiązek zachowania w tajemnicy informacji związanych $\mathrm{z}$ pacjentem, a uzyskanych w związku z wykonywaniem zawodu. Ustęp 2 głosi natomiast, że przepisu ust. 1 nie stosuje się, gdy: 1) tak stanowią ustawy; 2) badanie lekarskie zostało przeprowadzone na żądanie uprawnionych, na podstawie odrębnych ustaw, organów i instytucji; wówczas lekarz jest obowiązany poinformować o stanie zdrowia pacjenta wyłącznie te organy i instytucje; 3) zacho-

${ }^{3}$ P. Kardas, Konstytucyjne i ustawowe aspekty ochrony tajemnicy zawodowej powierzonej przedstawicielom zawodów zaufania publicznego, „Czasopismo Prawa Karnego i Nauk Penalnych" 2014, nr 4, s. 5-51.

${ }^{4}$ Konstytucja RP z dnia 2.04 .1997 r.; Dz.U. z 1997 r. Nr 78, poz. 483 z późn. zm.

${ }^{5}$ D. Rydlichowska, Tajemnica lekarska w postępowaniu karnym, „Prokuratura i Prawo" 2015, nr 9, s. 37-48. 
wanie tajemnicy może stanowić niebezpieczeństwo dla życia lub zdrowia pacjenta lub innych osób; 4) pacjent lub jego przedstawiciel ustawowy wyraża zgodę na ujawnienie tajemnicy po uprzednim poinformowaniu o niekorzystnych dla pacjenta skutkach jej ujawnienia; 5) zachodzi potrzeba przekazania niezbędnych informacji o pacjencie lekarzowi sądowemu; 6) zachodzi potrzeba przekazania niezbędnych informacji o pacjencie związanych z udzielaniem świadczeń zdrowotnych innemu lekarzowi lub uprawnionym osobom uczestniczącym w udzielaniu tych świadczeń.

Anna Huk podkreśla, że „decyzja o ujawnieniu określonych informacji i o zakresie jego ujawnienia będzie ostatecznie zależeć od oceny samego lekarza (...). Przesłanki decyzji lekarskiej muszą być z jednej strony uzależnione od ocen czysto medycznych, a z drugiej strony od - od innych okoliczności związanych z sylwetką samego pacjenta, jego stylem życia, sposobem zachowania" ${ }^{\prime}$. Trudno nie zgodzić się z przytoczoną teza, może jedynie poza tym, że to przede wszystkim względy medyczne powinny przesądzać o powstaniu obowiązku zwolnienia z tajemnicy, a tylko fakultatywnie inne przesłanki dotyczące osoby pacjenta. Te inne przesłanki dopiero w dalszej kolejności mogą uzasadniać skorzystanie $\mathrm{z}$ takiego zwolnienia z uwagi zwłaszcza na zagwarantowanie bezpieczeństwa zdrowotnego innym osobom.

Nadto należy zwrócić uwagę, że lekarz po śmierci pacjenta nie jest już związany tajemnicą lekarską. Grzegorz Sibiga zauważa, że pacjenta pozbawiono gwarancji autonomii informacyjnej z tego względu, że nie ma on uprawnienia do złożenia oświadczenia negatywnego zakazującego lekarzowi ujawnienia informacji osobom bliskim ${ }^{7}$. Nie można jednak w pełni zgodzić się z tym stanowiskiem, osoby bliskie mają bowiem prawo do zgłoszenia sprzeciwu zarówno uprzedniego, jak i następczego, które uniemożliwiają w praktyce skorzystanie $\mathrm{z}$ obowiązku zwolnienia z tajemnicy lekarskiej. Chociaż wprawdzie nie przewidziano procedury rozstrzygania sporów między biskimi, to jednak zgłoszenie już jednego sprzeciwu wprowadza automatyczną blokadę.

Ustęp 2a przedmiotowej ustawy stanowi natomiast, że w sytuacjach, o których mowa w ust. 2, ujawnienie tajemnicy może nastąpić wyłącznie $\mathrm{w}$ niezbędnym zakresie. Zwolnienia z tajemnicy lekarskiej, o którym mowa w ust. 3, nie stosuje się, jeśli ujawnieniu tajemnicy sprzeciwi się

${ }^{6}$ A. Huk, Tajemnica zawodowa lekarza, "Prokuratura i Prawo” 2001, nr 6, s. 69-85.

7 G. Sibiga, Po śmierci pacjenta nie ma już żadnych tajemnic, „Rzeczpospolita”, PCD 2016, nr 8, s. 11. 
inna osoba bliska w rozumieniu art. 3 ust. 1 pkt 2 ustawy z dnia 6 listopada 2008 r. o prawach pacjenta i Rzeczniku Praw Pacjenta.

\section{Zakres podmiotowy tajemnicy lekarskiej}

Tak więc sprzeciw takiej osoby bliskiej ma swoje uzasadnione znaczenie, zważywszy przede wszystkim na dobro osoby zakażonej czy będącej nosicielem choroby zakaźnej, zwłaszcza w sytuacji, w której ujawnienie tych informacji mogłoby być krzywdzące dla takich osób. Nadto należy podkreślić, że osobą bliską w rozumieniu art. 3 ust. 1 pkt 2 ustawy o prawach pacjenta i Rzeczniku Praw Pacjenta jest małżonek, krewny lub powinowaty do drugiego stopnia w linii prostej, przedstawiciel ustawowy, osoba pozostającą we wspólnym pożyciu lub osoba wskazana przez pacjenta. W odniesieniu do terminu „osoba pozostająca we wspólnym pożyciu" należy dodatkowo przywołać uchwałę Sądu Najwyższego, w której SN orzekł, że więź fizyczna między osobami pozostającymi we wspólnym pożyciu nie jest konieczna, wystarczy duchowa i ekonomiczna ${ }^{8}$. Wspólne pożycie może też dotyczyć osób tej samej płci. Odnosi się to co prawda do postępowania karnego, ale może również być wykorzystane w dookreśleniu zakresu podmiotowego prawa do informacji $\mathrm{w}$ dziedzinie zwolnienia z obowiązku zachowania tajemnicy lekarskiej w związku z chorobami zakaźnymi i zakażeniami. Również M. Boratyńska twierdzi, że pacjent ma prawo do tego, aby obdarzyć zaufaniem dowolną osobę, bez względu na relację rodzinna, towarzyską bądź status zawodowy ${ }^{9}$.

Rozszerzenie zakresu podmiotowego kręgu osób bliskich, w kontekście zwolnienia z obowiązku zachowania tajemnicy lekarskiej, z jednej strony niewątpliwie sprzyja zwiększonej ochronie interesu osoby zakażonej czy nawet będącej nosicielem wirusa HIV. Z drugiej strony natomiast w pewnym zakresie stanowi zagrożenie dla bezpieczeństwa zdrowotnego innych osób.

Co więcej, zgodnie z art. 31 ust. 1 ustawy o zawodach lekarza i lekarza dentysty, lekarz ma obowiązek udzielać pacjentowi lub jego ustawowemu przedstawicielowi przystępnej informacji o jego stanie zdrowia, roz-

\footnotetext{
8 Por. uchwała 7 sędziów SN z 25 lutego 2016 r., I KZP 20/15.

${ }_{9}$ M. Boratyńska, Autonomia pacjenta a granice upoważnienia osoby bliskiej i zaufanej, „Prawo i Medycyna" 2014, nr 1, s. 61-85.
} 
poznaniu, proponowanych oraz możliwych metodach diagnostycznych, leczniczych, dających się przewidzieć następstwach ich zastosowania albo zaniechania, wynikach leczenia oraz rokowaniu. Ustęp 2 stanowi zaś, że lekarz może udzielić takich informacji innym osobom za zgodą pacjenta lub jego przedstawiciela ustawowego. Zgodnie z powyższym wyłącznie za zgodą pacjenta taka informacja o stanie zdrowia może zostać udostępniona osobom trzecim, $\mathrm{w}$ tym małżonkowi pacjenta.

Tak więc z jednej strony zwolnienie lekarza z obowiązku zachowania tajemnicy zawodowej uzasadnia stan zagrożenia dla życia lub zdrowia w przypadku wystąpienia choroby zakaźnej. Z drugiej natomiast charakterystyczne są pewne sytuacje wyjątkowe, takie jak niezdolność do zrozumienia znaczenia informacji czy nieprzytomność pacjenta. Wtedy, wyjątkowo, także informacje dotyczące choroby zakaźnej mogą zostać przekazane bez zgody pacjenta. Potwierdził to SA w Poznaniu w wyroku z dnia 9.05.2002 r., w którym orzekł, że na personelu medycznym spoczywa obowiązek poinformowania innych osób o stanie zdrowia pacjenta, „niezależnie od tego czy wynikał on z treści przepisów prawa stosowanego"10. Co więcej, „szkoda pacjenta jest mniejsza, bo co najwyższej mógłby on podjacć wcześniej leczenie, natomiast szkoda osób najbliższych (najczęściej małżonka i dzieci) w ogóle by nie powstała, gdyby o chorobie zakaźnej zostali powiadomieni w odpowiednim czasie. Jeżeli pacjent został zakażony w szpitalu, jego szkoda obejmuje wszelkie skutki, takie jak jego najbliższych"11.

Powyższe przypadki zostały przewidziane w art. 34 ust. 6 przywołanej ustawy, który stanowi, iż jeżeli przedstawiciel ustawowy pacjenta małoletniego, ubezwłasnowolnionego bądź niezdolnego do świadomego wyrażenia zgody nie zgadza się na wykonanie przez lekarza czynności wymienionych $w$ ust. 1 , a niezbędnych do usunięcia niebezpieczeństwa utraty przez pacjenta życia lub ciężkiego uszkodzenia ciała bądź ciężkiego rozstroju zdrowia, lekarz może wykonać takie czynności po uzyskaniu zgody sądu opiekuńczego. Ustęp 8 tegoż artykułu głosi, że o okolicznościach, o których mowa w ust. 3-7, lekarz informuje pacjenta oraz jego przedstawiciela ustawowego lub opiekuna faktycznego albo sąd opiekuńczy, a także dokonuje odpowiedniej adnotacji wraz z uzasadnieniem w dokumentacji medycznej.

\footnotetext{
10 ACa 221/02, „Prawo i Medycyna” 2004, nr 1.

11 Tamże.
} 
Bezdyskusyjne jest zatem, że tylko wtedy lekarz jest obowiązany udostępnić informację przedstawicielowi ustawowemu lub opiekunowi faktycznemu pacjenta bez zgody pacjenta. Zakres przedmiotowy pojęcia „opiekun faktyczny” według art. 3 ust. 1 pkt 1 ustawy z dnia 6.11.2008 r. o prawach pacjenta i Rzeczniku Praw Pacjenta ${ }^{12}$ jest bardzo szeroki. Opiekunem faktycznym jest bowiem osoba sprawująca bez obowiązku ustawowego stałą opiekę nad pacjentem, który ze względu na wiek, stan zdrowia albo stan psychiczny wymaga takiej opieki. Opiekunem faktycznym może być zatem także małżonek pacjenta albo inna osoba, niekoniecznie spokrewniona $\mathrm{z}$ pacjentem. To rozwiązanie niewątpliwie należy ocenić pozytywnie, zważywszy szczególnie na konieczność wprowadzenia ograniczeń w rozprzestrzenianiu się ogniska zakażenia. Szeroki zakres podmiotowy pojęcia „opiekun faktyczny” z pewnością temu służy i może przyczynić się w praktyce do szybkiego zapobiegania zarówno zakażeniom, jak i chorobom zakaźnym.

Ponadto o obowiązku zwolnienia z zachowania tajemnicy lekarskiej stanowi art. 25 Kodeksu etyki lekarskiej, który głosi, że zwolnienie z zachowania tajemnicy lekarskiej może nastąpić: gdy pacjent wyrazi na to zgodę, jeśli zachowanie tajemnicy w sposób istotny zagraża zdrowiu lub życiu pacjenta lub innych osób oraz jeśli zobowiązują do tego przepisy prawa ${ }^{13}$. Gwarancja zawarta w ustawie o zawodach lekarza i lekarza dentysty znajduje zatem także potwierdzenie w skodyfikowanych zasadach etyki zawodowej, co ma umocowanie w normach moralnych warunkujących wykonywanie zawodu lekarza.

\section{Odpowiedzialność prawna za naruszenie tajemnicy lekarskiej}

Za naruszenie obowiązku zachowania tajemnicy lekarskiej, również dotyczącej zakażeń i chorób zakaźnych, lekarz może ponieść odpowiedzialność karną, cywilną i zawodową.

12 Ustawa z dnia 6.11.2008 r. o prawach pacjenta i Rzeczniku Praw Pacjenta, tekst jedn., Dz.U. z 2016 r., poz. 186 z późn. zm.

${ }^{13}$ Uchwała Nadzwyczajnego II Krajowego Zjazdu Lekarzy z dnia 14.12.1991 z późn. zm., www.nil.org.pl/_data/assets/pdf_file/0003/4764/Kodeks-Etyki-Lekarskiej.pdf (dostęp: 20.06.2017 r.). 
Odpowiedzialność karna lekarza jest unormowana na gruncie art. 266 Kodeksu karnego ${ }^{14}$. Artykuł $266 \S 1$ głosi, że kto, wbrew przepisom ustawy lub przyjętemu na siebie zobowiązaniu, ujawnia lub wykorzystuje informację, z którą zapoznał się w związku z pełnioną funkcją, wykonywaną praca, działalnością publiczna, społeczna, gospodarczą lub naukowa podlega grzywnie, karze ograniczenia wolności albo pozbawienia wolności do lat 2. Paragraf 2 głosi natomiast, że funkcjonariusz publiczny, który ujawnia osobie nieuprawnionej informację niejawną o klauzuli „zastrzeżone” lub „poufne” lub informację, którą uzyskał w związku z wykonywaniem czynności służbowych, a której ujawnienie może narazić na szkodę prawnie chroniony interes, podlega karze pozbawienia wolności do lat 3. Zgodnie z § 3 ściganie przestępstwa określonego w $§ 1$ następuje na wniosek pokrzywdzonego, niemniej jednak trzeba zauważyć, że aby można było mówić o wyczerpaniu zakresu przedmiotowego tegoż artykułu, muszą wystąpić następujące przesłanki.

Po pierwsze, informację o zakażeniu czy chorobie zakaźnej lekarz musi pozyskać lub wykorzystać w związku z wykonywaniem czynności zawodowych, a nie prywatnie. Jak słusznie podkreśla M. Szewczyk, obowiązek zachowania $\mathrm{w}$ tajemnicy tych informacji rozpoczyna się już w chwili ich uzyskania, a nie tylko udostępnienia innym podmiotom czy osobom $^{15}$. Po drugie, jak zauważają A. Liszewska i W. Robaczyński, po stronie lekarza musi wystąpić bezprawność takiego zachowania ${ }^{16}$. To znaczy, że w działaniu lub zaniechaniu lekarza musi wystąpić zamiar bezpośredni lub zamiar ewentualny. Po trzecie, takie przestępstwo jest ścigane na wniosek pokrzywdzonego, jego najbliższych (w sytuacji gdy pokrzywdzony umrze) bądź prokuratora (art. 52 Kodeksu postępowania karnego $)^{17}$. Należy podkreślić, powtarzając za W. Kulesza, że na gruncie obowiązujących przepisów, korzystnie zwłaszcza dla obrony interesu pokrzywdzonego pacjenta, tajemnica lekarska zmieniła charakter służbowy na zawodowy ${ }^{18}$.

${ }^{14}$ Ustawa z dnia 6.06.1997 r. - Kodeks karny, tekst jedn., Dz.U. z 2016 r. poz. 1137 z późn. zm.

${ }^{15}$ M. Szewczyk, Prawnokarna ochrona tajemnicy zawodowej lekarza, "Czasopismo Prawa Karnego i Nauk Penalnych" 2000, z. 1, s. 169.

16 A. Liszewska, W. Robaczyński, AIDS a tajemnica lekarska, Poznań 2001, s. 51.

17 Ustawa z dnia 6.06.1997 r. - Kodeks postępowania karnego, tekst jedn., Dz.U. z 2016 r., poz. 1749 z późn. zm.

${ }^{18}$ W. Kulesza, AIDS a prawnokarne problemy tajemnicy lekarskiej, [w:] A.J. Szwarc (red.), AIDS i prawo karne, Poznań 1996, s. 70 i n. 
Odpowiedzialność zawodową lekarz może ponieść na podstawie przepisów ustawy z dnia 2.12.2009 r. o izbach lekarskich ${ }^{19} \mathrm{w}$ przypadku naruszenia zasad etyki albo przepisów związanych z wykonywaniem zawodu, czyli zarówno art. $25 \mathrm{KEL}$, jak i art. 40 ust. 2, art. 31 ust. 1 i 2 oraz art. 34 ust. 6 i 8 ustawy o zawodach lekarza i lekarza dentysty.

Dodatkowo lekarz może ponieść odpowiedzialność cywilną za naruszenie dóbr osobistych na podstawie art. 23 Kodeksu cywilnego, który głosi, iż dobra osobiste człowieka, jak w szczególności zdrowie, wolność, cześć, swoboda sumienia, nazwisko lub pseudonim, wizerunek, tajemnica korespondencji, nietykalność mieszkania, twórczość naukowa, artystyczna, wynalazcza i racjonalizatorska, pozostają pod ochroną prawa cywilnego niezależnie od ochrony przewidzianej w innych przepisach ${ }^{20}$. Zdrowie, jako dobro najwyższe, jest także szczególnie chronione przez przepisy Kodeksu cywilnego.

Należy zauważyć, że ochrona przysługuje pokrzywdzonemu wskutek działań lekarza skutkujących nieuprawnionym ujawnieniem tajemnicy lekarskiej na podstawie art. 448 k.c. Zgodnie z tym artykułem w razie naruszenia dobra osobistego sąd może przyznać temu, czyje dobro osobiste zostało naruszone, odpowiednią sumę tytułem zadośćuczynienia pieniężnego za doznaną krzywdę lub na jego żądanie zasądzić odpowiednią sumę pieniężną na wskazany przez niego cel społeczny, niezależnie od innych środków potrzebnych do usunięcia skutków naruszenia.

Jakikolwiek sposób ujawnienia informacji, jak i wyników badań osoby chorej na chorobę zakaźną lub zakażonej stanowi naruszenie jej dobra osobistego i dodatkowo praw pacjenta w rozumieniu przepisów ustawy z dnia 6.11.2008 r. o prawach pacjenta i Rzeczniku Praw Pacjenta.

Artykuł 4 ust. 1 tejże ustawy stanowi, że w razie zawinionego naruszenia praw pacjenta sąd może przyznać poszkodowanemu odpowiednią sumę tytułem zadośćuczynienia pieniężnego za doznaną krzywdę na podstawie art. 448 Kodeksu cywilnego. Przekazanie informacji osobom nieuprawnionym stanowi krzywdę, ale w pewnych sytuacjach może także przybierać formę szkody majątkowej. Taką sytuacją może być chociażby utrata pracy czy innej formy zarobkowania przez osobę będącą nosi-

19 Ustawa z dnia 2.12.2009 r. o izbach lekarskich, tekst jedn., Dz.U. z 2016 r., poz. 522 z późn. zm.

${ }^{20}$ Ustawa z dnia 23.04.1964 r. - Kodeks cywilny, tekst jedn. Dz.U. 2017 r. poz. 459 z późn. zm. 
cielem wirusa w wyniku udostępnienia tych informacji pracodawcy czy innemu podmiotowi zatrudniającemu.

\section{Zapobieganie zakażeniom i chorobom zakaźnym w podmiotach leczniczych}

Na podmiotach leczniczych ciąży obowiązek zapobiegania zakażeniom i chorobom zakaźnym. Powyższe twierdzenie znajduje uzasadnienie w następującej argumentacji.

Po pierwsze, szpital wiąże z pacjentem obowiązek hospitalizacji i zabiegów medycznych, który zakłada powinność zapewnienia pacjentowi bezpieczeństwa o charakterze rezultatu. To szpital może zatem zwolnić się od odpowiedzialności poprzez wykazanie przyczyny zewnętrznej, czyli braku związku przyczynowego pomiędzy stanem zdrowia pacjenta a jego pobytem w szpitalu. Na szpitalu jako potencjalnym sprawcy szkody spoczywa ciężar dowodu na brak winy. Należy więc uznać, że szkoda wyrządzona pacjentowi na skutek zakażenia go chorobą zakaźną jest domniemaniem niedbalstwa szpitala i zawsze (słusznie) dowód ekskulpacji spoczywa na szpitalu. To szpital musi bowiem udowodnić brak winy po swojej stronie, aby zwolnić się z odpowiedzialności za powstałą szkodę na osobie pacjenta podczas hospitalizacji.

Dodatkowo dowód prima facie należy stosować na podstawie art. 231 k.p.c., zgodnie z którym można uznać za ustalone fakty mające istotne znaczenie dla rozstrzygnięcia sprawy, jeżeli wniosek taki można wyprowadzić z innych ustalonych faktów. Potwierdził to Sąd Apelacyjny w Warszawie w wyroku z dnia 21.03.1997 r., w którym stwierdził, ,,że w sprawach w których w grę wchodzi odpowiedzialność placówki leczniczej służby zdrowia, nie jest na ogół możliwe stwierdzenie z całkowitą pewnością że przyczynę zakażenia stanowiło konkretne zdarzenie. Dopuszczalne jest zatem ustalenie tego faktu na podstawie dowodów pośrednich, o ile zachodzi wysokie prawdopodobieństwo jego zajścia" ${ }^{21}$. Słusznie wysoki stopień prawdopodobieństwa jest zawsze brany pod uwagę, niejednokrotnie trudno jest bowiem jednoznacznie wskazać pewną przesłankę zakażenia. Dlatego już samo prawdopodobieństwo graniczące z pewnością zasadnie

\footnotetext{
${ }^{21}$ I ACa 107/97, „Wokanda” 1998, nr 7.
} 
przemawia za przypisaniem winy. Taka praktyka jest ważna szczególnie w odniesieniu do chorób zakaźnych i zakażeń.

Tak więc w procesach sądy dążą do ustalenia prawdopodobieństwa zarówno zakażenia, jak i powstania ogniska choroby zakaźnej w pozwanych szpitalach. Jeżeli to prawdopodobieństwo jest wysokie, graniczące z pewnościa, uwzględniają powództwo ${ }^{22}$. Bardzo często występowanie jakichkolwiek nieprawidłowości przesądza o wystąpieniu szkody na osobie pacjenta. Co więcej, ,jeżeli kontrola przeprowadzona w szpitalu wskazuje na nieprawidłowości w zakresie zapobiegania zakażeniom szpitalnym, to można uznać, że do zakażenia (...) doszło z dużą dozą prawdopodobieństwa na skutek zaniedbań w tym szpitalu"23.

Do tych zaniedbań najczęściej należą: nieprzestrzeganie zasad aseptyki i antyseptyki w podmiotach leczniczych, brak właściwej i skutecznej kontroli czy wreszcie nienależyty nadzór epidemiologiczny. Wszystkie te zaniedbania, łącznie $\mathrm{z}$ winą po stronie pracowników medycznych, mogą w dużym stopniu stanowić przyczynę wystąpienia zakażenia czy choroby zakaźnej.

Po drugie, obowiązujące przepisy chronią jednak i powoda, który może być potencjalnym sprawcą szkody. Nie wymagają od niego bowiem dowodzenia niemożliwego do przeprowadzenia $\mathrm{w}$ praktyce. Już SN w wyroku z dnia 13.06.2000 r. orzekł, że wykazanie znaczącego prawdopodobieństwa między określonymi działaniami szpitala i zakażeniem pozwala przyjąć, że powód spełnił obowiązek przeprowadzenia dowodu (art. 6 k.c.), nie można bowiem stawiać przed powodem nierealnego wymagania ścisłego wykazania momentu i drogi przedostania się infekcji do organizmu" ${ }^{24}$. Zatem słusznie SN dodatkowo potwierdził w takich przypadkach brak obowiązku ekskulpacji. Zasadnie stopień prawdopodobieństwa wystąpienia zakażenia w związku z domniemaną winą pracowników medycznych stanowi przesłankę uzasadniającą powstanie takiej odpowiedzialności.

Podmiot leczniczy jest zobowiązany do dołożenia należytej staranności w celu ochrony pacjentów przed niebezpieczeństwem zakażenia

${ }^{22}$ M. Nesterowicz, Prawo medyczne, wyd. 11, Toruń 2016, s. 112.

${ }^{23}$ Tenże, Glosa do wyroku SA w Warszawie z dnia 30.10.2015 r., I ACa 189/15, odpowiedzialność szpitala za zakażenia bakteryjne podczas porodu. Prawo medyczne. Komentarze i glosy do orzeczeń sądowych, Warszawa 2017, s. 419.

${ }^{24}$ V CKN 34/00, LEX nr 52689, a także wyrok SN z dnia 27.02.1998 r., II CKN 625/97, M. Nesterowicz, Prawo medyczne..., s. 110-118, 447 i n. 
chorobą zakaźną. Ten obowiązek bezpośrednio wiąże się z koniecznością zapewnienia bezpieczeństwa zdrowotnego wszystkim hospitalizowanym pacjentom. To przede wszystkim poczucie pewności, że hospitalizacja pacjentów nie jest obarczona ryzykiem zagrożeń dla ich życia i zdrowia, służy budowaniu przekonania o bezpieczeństwie takiego pobytu w podmiocie leczniczym. Jeżeli naruszenie tego obowiązku powoduje zwiększenie ryzyka infekcji i z tym właśnie ryzykiem łączy się choroba zakaźna pacjenta, zakład leczniczy ponosi odpowiedzialność za doznaną przez pacjenta szkodę.

Po trzecie, co więcej, SN w wyroku z dnia 17.07.1974 r. (II CR 415/74) orzekł, „że nie można stawiać powodowi nierealnego wymagania ścisłego udowodnienia, jakimi drogami infekcja przedostała się do organizmu. Dlatego też w takiej sytuacji, jeżeli pozwany szpital twierdzi, że infekcja pochodzi z innych źródeł, powinien to udowodnić' ${ }^{25}$.

Ciężar dowodu w takiej sytuacji spoczywa zatem na pozwanym, to właśnie on musi udowodnić brak winy po swojej stronie. Musi wykazać, że dana infekcja pochodzi z innych źródeł, aby uwolnić się od odpowiedzialności. Słusznie, że to właśnie pozwany, a nie powód musi udowodnić w takiej sytuacji brak winy. Obciążenie powoda dowodem braku winy byłoby niezmiernie dużym wyzwaniem i naruszałoby zasadę równości stron w procesie. To w interesie pozwanego leży bowiem wykazanie dowodów braku winy po swojej stronie.

Po czwarte, również w orzeczeniu Sądu Apelacyjnego w Krakowie z dnia 14.10.1992 r. stwierdzono, że: „zakład leczniczy jest zobowiązany do dołożenia należytej staranności w celu ochrony pacjentów przed niebezpieczeństwem zakażenia chorobą zakaźną. Zapewnienie bezpieczeństwa zdrowotnego pacjentom powinno być priorytetem dla każdego podmiotu leczniczego. Brak działań w tym zakresie bądź też zaniechania zawsze obciążają placówkę medyczną" ${ }^{26}$. Wymaganie od osoby poszkodowanej, aby wykazała bezpośredni związek przyczynowy pomiędzy zachowaniem zwiększającym ryzyko infekcji a zakażeniem szpitalnym, łączyłoby się dla osoby poszkodowanej z trudnościami dowodowymi niedającymi się przezwyciężyć w praktyce ${ }^{27}$. Wykazanie tego związku przyczynowego czyniłoby niemożliwym przeprowadzenie takiego dowodu.

\footnotetext{
${ }^{25}$ Wyrok SN z dnia 17.07.1974 r., II CR 415/74.

${ }^{26}$ I Acr 374/92, OSA Kr II, poz. 44.

${ }^{27}$ Wyrok SN z 13.06.2000 r., V CKN 34/00, LEX nr 52689.
} 
Po piąte, powszechnie wiadomo, że każdy podmiot leczniczy jest zobowiązany do dołożenia należytej staranności w celu ochrony pacjentów przed niebezpieczeństwem zakażenia chorobą zakaźną. Zachowanie należytej staranności nieodłącznie wiąże się z obligatoryjnym przestrzeganiem wszystkich standardów postępowania, a przede wszystkim wzorców dobrego lekarza, który wdraża właściwe postępowanie w konkretnych jednostkach chorobowych. Jeżeli naruszenie tego obowiązku powoduje zwiększenie ryzyka infekcji i z tym właśnie ryzykiem łączy się choroba zakaźna pacjenta lub zakażenie, to zawsze zakład leczniczy ponosi odpowiedzialność za doznaną przez pacjenta szkodę. O odpowiedzialności może przesądzić także wina umyślna, chociaż w przeważającej większości przypadków jest to wina nieumyślna, której najczęstszymi postaciami są niedbalstwo lub lekkomyślność. Wina taka musi wystąpićłącznie z powstałą szkoda, co więcej, muszą być powiązane adekwatnym związkiem przyczynowo-skutkowym.

Po szóste, zasadne jest twierdzenie, że gdyby w organizmie nie wykryto bakterii, mógłby się bronić w sposób bardziej skuteczny chociażby przed narastającą niewydolnością serca czy innego narządu. Podobnie słuszne jest wskazywanie, że narastające objawy, ze względu na przykład na obecność bakterii we krwi, rurce intubacyjnej oraz końcówce cewnika, mogą bezwzględnie przyczynić się do śmierci. Osłabiony organizm na skutek występowania bakterii z pewnością ma dużo mniejsze szanse na wygranie z ciężką chorobą. Traktowanie czynnika biologicznego jako głównej przyczyny zgonu w takim przypadku wydaje się być uzasadnione. W pierwszej kolejności chroni bowiem osobę pokrzywdzoną wskutek zakażenia czy też choroby zakaźnej, a dopiero w dalszej obejmuje ochroną pozwanego, który jest odpowiedzialny za wyrządzenie tej szkody.

Ponadto występowanie gronkowca złocistego weryfikują już wstępne badania mikrobiologiczne. Na ich podstawie stwierdza się obecność gronkowca złocistego w organizmie. Powyższe znajduje potwierdzenie w wyroku SN z dnia 29.12.1969 r., w którym Sąd Najwyższy orzekł, „że w przypadku zakażenia gronkowcem złocistym do poszkodowanego należy dowód, że wchodząc do szpitala nie był zakażony (co powinny wykazać wyniki badań wstępnych) i że w trakcie pobytu w szpitalu doznał infekcji. Przeprowadzenie takiego dowodu pozwoli na przyjęcie domniemania niedbalstwa szpitala w zakresie zapewnienia choremu bezpieczeństwa pobytu" ${ }^{28}$. Takim

\footnotetext{
${ }^{28}$ II CR 551/69, OSPiKA.
} 
dowodem są najczęściej badania przeprowadzone w trakcie przyjmowania pacjenta do szpitala, z których jednoznacznie wynika, że nie był on zakażony gronkowcem złocistym. Przeprowadzenie kolejnych badań, z których wynika, że wykryto u niego gronkowca złocistego, niepodważalnie wskazuje na fakt, iż do zakażenia doszło właśnie w trakcie hospitalizacji.

Po siódme, nawet gdyby nie stwierdzono żadnych uchybień w trakcie realizacji procedur medycznych, to jednak niezwykle trudno jest wykluczyć brak niewłaściwej aseptyki pomieszczeń i narzędzi w związku z zaistniałym zakażeniem gronkowcem złocistym. To właśnie przede wszystkim niezachowanie aseptyki i antyseptyki prowadzi do powstania takiego zakażenia. Co więcej, każda rana szpitalna, z której wycieka ropa, uważana jest za zakażoną szpitalnie ${ }^{29}$. Słusznie, ponieważ w takim przypadku istnieje największe ryzyko wystąpienia zakażenia. Należy zatem wysnuć wniosek, że gdyby nie doszło do popełnienia żadnych nieprawidłowości, to z pewnością zakażenie nie wystąpiłoby. Zaistniałe nieprawidłowości definitywnie przesądzają o tym, że do zakażenia może dojść w trakcie hospitalizacji.

\section{Podsumowanie}

Gwarancje ustawowe dotyczące zwolnienia z obowiązku zachowania tajemnicy lekarskiej powinny skutecznie służyć zwalczaniu zakażeń i chorób zakaźnych. Także możliwość poniesienia odpowiedzialności prawnej przez lekarza za złamanie tych obwarowań prawnych mogłoby się wydawać, że sprzyja ich wykluczaniu i ograniczaniu. Przestrzeganie zasad aseptyki i antyseptyki w podmiotach leczniczych też z pewnością skutkuje eliminowaniem takich zagrożeń. Niemniej jednak najważniejszą przesłankę stanowi zachowanie przez lekarzy i innych pracowników medycznych zasad należytej staranności w wykonywaniu czynności zawodowych zgodnie z wzorcami dobrego lekarza, dobrej pielęgniarki czy dobrej położnej. Należy podkreślić, że niewątpliwie dopiero wszystkie łącznie elementy składające się na stan likwidowania zagrożeń w podmiotach leczniczych wraz z uregulowaniami prawnymi w zakresie zwolnienia z obowiązku zachowania tajemnicy lekarskiej mogą przyczynić

\footnotetext{
${ }^{29}$ L. Jabłoński, Epidemiologia, Lublin 1996, s. 215.
} 
się do ograniczenia rozprzestrzeniania i występowania zakażeń i chorób zakaźnych.

Słowa kluczowe: choroba zakaźna, zakażenie, zwalczanie, zapobieganie.

\section{Bibliografia}

Boratyńska M., Autonomia pacjenta a granice upoważnienia osoby bliskiej i zaufanej, „Prawo i Medycyna” 2014, nr 1.

Huk A., Tajemnica zawodowa lekarza, „Prokuratura i Prawo” 2001, nr 6.

Jabłoński L., Epidemiologia, Lublin 1996.

Kardas P., Konstytucyjne i ustawowe aspekty ochrony tajemnicy zawodowej powierzonej przedstawicielom zawodów zaufania publicznego, "Czasopismo Prawa Karnego i Nauk Penalnych" 2014, nr 4.

Kubiak R., Prawo medyczne, Warszawa 2014.

Kulesza W., AIDS a prawnokarne problemy tajemnicy lekarskiej, [w:] A.J. Szwarc (red.), AIDS i prawo karne, Poznań 1996.

Liszewska A., Robaczyński W., AIDS a tajemnica lekarska, Poznań 2001.

Nesterowicz M., Glosa do wyroku SA w Warszawie z dnia 30.10.2015 r., I ACa 189/15, odpowiedzialność szpitala za zakażenia bakteryjne podczas porodu, Prawo medyczne. Komentarze i glosy do orzeczeń sądowych, Warszawa 2017.

Nesterowicz M., Prawo medyczne, wyd. 11, Toruń 2016.

Rydlichowska D., Tajemnica lekarska w postępowaniu karnym, „Prokuratura i Prawo" 2015, nr 9.

Sibiga G., Po śmierci pacjenta nie ma już żadnych tajemnic, „Rzeczpospolita”, PCD 2016, nr 8.

Szewczyk M., Prawnokarna ochrona tajemnicy zawodowej lekarza, „Czasopismo Prawa Karnego i Nauk Penalnych" 2000, z. 1.

\section{Wykaz orzecznictwa}

Wyrok SN z dnia 29.12.1969 r., II CR 551/69, OSPiKA.

Wyrok SN z dnia 27.02.1998 r., II CKN 625/97, M. Nesterowicz, Prawo medyczne, wyd. 11, Torun 2016 r., s. 110-118, 447 i n.

Wyrok SN z dnia 13.06.2000 r., V CKN 34/00, LEX nr 52689.

Uchwała 7 sędziów SN z 25 lutego 2016 r., I KZP 20/15.

Wyrok SA w Krakowie z dnia 14.10.1992 r., I Acr 374/92, OSA Kr II, poz. 44.

Wyrok SA w Warszawie z dnia 21.03.1997 r., I ACa 107/97, „Wokanda” 1998, nr 7. 


\section{PREVENTION AND COMBATING OF CONTAGIOUS DISEASES \\ AND INFECTIONS IN THE CONTEXT OF EXEMPTIONS \\ FROM DOCTOR-PATIENT CONFIDENTIALITY}

\section{S u m m a r y}

The aim of the paper is to present the legal regulations and the positions of the doctrine and the judicature concerning exemption of a physician from a duty of maintaining doctor-patient confidentiality with respect to prevention and combating of contagious diseases and infections. Pursuant to the Act of 05.12.1996 on the Professions of a Doctor and a Dentist, a physician is obliged to maintain doctor-patient confidentiality. Article 40 section 1 of the Act provides that a physician has a duty to keep confidential patient-related information obtained in connection with practising the profession. On the other hand, section 2 provides that the regulation contained in section 1 is not applied when: maintaining confidentiality can pose a danger to life or health of the patient or other people. The statutory guarantees pertaining to exemption from doctor-patient confidentiality should effectively serve to combat contagious diseases and infections. Moreover, possible legal responsibility that a physician can bear for breaking these regulations seems to support exemptions and restrictions of these rules.

Keywords: infectious disease, infection, control, prevention.

\section{ПРОТИВОДЕЙСТВИЕ ИНФЕКЦИЯМ И ИНФЕКЦИОННЫМ БОЯЕЗНЯМ В ЛЕЧЕБНЫХ СУБЪЕКТАХ В КОНТЕКСТЕ ОСВОБОЖДЕНИЯ ИЗ ОБЯЗАННОСТИ СОХРАНЕНИЯ ВРАЧЕБНОЙ ТАЙНЫ}

$$
\text { P е } 3 \text { ю м е }
$$

Целью статьи является представление юридических нормирований, а также позиции доктрины и вынесения решения, что касается освобождения врача из обязанности сохранения врачебной тайны для предотвращения и борьбы с инфекционными болезнями и инфекциями. Согласно с законом от 05.12.1996 г. о профессии врача и врача-стоматолога, врач обязан сохранить врачебною тайну. Ст. 40 п. 1 содержит, что врач обязан сохранить в тайне информации, связанные с пациентом и полученных в связи с выподнением профессии. Но п. 2 содержит, что положение п. 1 не применяется, если: 3) сохранение тайны может быть опасным для жизни или здоровья пациента или других лиц. Законодательные гарантии, касающиеся освобождения из обязанности сохранения врачебной тайны, должны быть эффективными в борьбе с инфекционными болезнями и инфекциями. Также возможность нести юридическою ответственность врачом за нарушение правовых условий, 
какие могли бы быть вероятными, что способствуют их исключению и ограничению.

Ключевые слова: инфекционная болезнь, инфекция, борьба, предотвращение. 